\title{
SEX DISCRIMINATION IN RESTAURANT \\ HIRING: AN AUDIT STUDY
}

\author{
David Neumark \\ Roy J. Bank \\ Kyle D. Van Nort
}

Working Paper No. 5024

\section{NATIONAL BUREAU OF ECONOMIC RESEARCH 1050 Massachusetts Avenue \\ Cambridge, MA 02138 \\ February 1995}

Bank and Van Nort were students in an undergraduate research seminar who were instrumental in the planning and implementation of this project. We are grateful to Wendy Stock for outstanding research assistance, to Susan Tsu and Charles Gassenheimer for assistance with the study, and to Jim Heckman, Harry Holzer, and Paul Menchik for helpful comments. This paper is part of NBER's research program in Labor Studies. Any opinions expressed are those of the authors and not those of the National Bureau of Economic Research.

() 1995 by David Neumark, Roy J. Bank, Kyle D. Van Nort. All rights reserved. Short sections of text, not to exceed two paragraphs, may be quoted without explicit permission provided that full credit, including (C) notice, is given to the source. 


\title{
SEX DISCRIMINATION IN RESTAURANT HIRING: AN AUDIT STUDY
}

\begin{abstract}
This paper reports on a small-scale audit study that investigates sex discrimination in restaurant hiring. Comparably matched pairs of men and women applied for jobs as waiters and waitresses at 65 restaurants in Philadelphia. The 130 applications led to 54 interviews and 39 job offers. The results provide statistically significant evidence of sex discrimination against women in high-price restaurants. In high-price restaurants, job applications from women had an estimated probability of receiving a job offer that was lower by about .5 , and an estimated probability of receiving an interview that was lower by about .4 . These hiring patterns appear to have implications for sex differences in earnings, as informal survey evidence indicates that earnings are higher in high-price restaurants.
\end{abstract}

David Neumark

Department of Economics

Michigan State University

East Lansing, MI 48824

and NBER

Kyle D. Van Nort

2200 Ben Franklin Parkway

Philadelphia, PA 19130
Roy J. Bank

Eastern Mortgage Services, Inc. 2655 Interplex Drive

Trevose, PA 19053 


\section{Introduction}

The overall sex gap in wages can be broken into an across-occupation and a withinoccupation component. The sex gap related to across-occupation segregation has alternatively been attributed to human capital investment (Polachek, 1981), preferences. (Daymont and Andrisani, 1984), and employment discrimination (Beller, 1982; Bergmann, 1974). The sex gap that remains within occupations may reflect pure pay discrimination between men and women working alongside one another. Or it may reflect segregation across jobs, within occupations, sometimes called "vertical segregation" (Berch, 1982). ${ }^{1}$ Such segregation may arise for the same reasons as segregation across occupations.

In this paper we investigate the role of discrimination in vertical segregation among waiters and waitresses. Data from the mid-1980s indicate a sizable sex gap in wages even in the narrow occupation of waiters and waitresses. Bergmann reports that, for waiters and waitresses who usually worked full-time, the ratio of median earnings of women relative to men was .8 (1986, p. 124). Along what dimensions might vertical segregation among waiters and waitresses contribute to this earnings gap? Although there is no existing hard evidence on this point, researchers on sex differences in labor markets have suggested that males are favored in high-price, formal restaurants, where wages and tips are higher. ${ }^{2}$ In Pink Collar Workers, Howe writes that in "the heart of Manhattan's most expensive restaurant district, there were only a relative handful of "tablecloth restaurants" that hired

${ }^{1} \mathrm{~A}$ good example of vertical segregation is provided in an analysis of the PATC survey by Sieling (1984). He shows that within occupations such as accountant, auditor, attorney, buyer, drafter, computer operator, etc., women are disproportionately represented in lower-level jobs (e.g., "Accountant I" versus "Accountant IV") in which average pay is lower.

${ }^{2}$ There is no large-scale data set of which we are aware that would permit the comparison of earnings of waitpersons in high- and low-price restaurants. 
women for anything but hat-checking. At the same time further uptown and downtown, farther west and east, throughout the other boroughs ... the overwhelming majority of those serving food were women" (1977, p. 104). Howe also cites the 1972-1973 U.S. Department of Labor Occupational Outlook Handbook noting that "Jobs for waiters tended to be concentrated in those restaurants, hotel dining rooms, private clubs, and other establishments where meal service was formal," and she claims that wages and tips are highest in precisely those jobs in which waiters are concentrated (p. 104). Similarly, Bergmann claims that friction between waitresses and other male employees in restaurants leads to the segregation of waiters into high-price restaurants, and waitresses into low-price restaurants. She writes that, "In American restaurants that offer fine food and/or a luxurious setting, the size of the check allows for tips big enough to attract male waiters. In cheaper restaurants, the owners put up with the friction rather than supplement the tips to an extent necessary to be able to have male waiters" (1986, p. 99n). Furthermore, Bergmann claims that "Many of the restaurants that employ ... male waiters have never hired a waitress," (p. 124) and if they do, they have "assigned them to different parts of the restaurant or different shifts, with the males getting the assignments in which the tips are higher" (p. 124n). ${ }^{3}$

To investigate the potential role of sex discrimination in vertical segregation among waiters and waitresses, we conducted a small-scale "audit study" patterned on studies of race discrimination in hiring pioneered by researchers at the Urban Institute (Cross, et al., 1990; Turner, et al., 1991; Kenney and Wissoker, 1994). Specifically, as part of a research project in an undergraduate economics research seminar, we sent two male and two female college students to apply for jobs as waiters and waitresses at 65 restaurants in Philadelphia.

\footnotetext{
${ }^{3}$ Bergmann does suggest, however, that "Recently, some restaurants have started using males and females interchangeably" (p. 124n).
} 
We divided the restaurants into high-, medium-, and low-price categories, with the goal of estimating sex differences in the receipt of job offers in each price category. We designed the study so that a male and female pair applied for a job at each restaurant, and so that, on paper at least, the male and female candidates were on average identical. The 130 attempts to obtain jobs resulted in 39 job offers.

Our findings provide strong evidence of discrimination against women in high-price restaurants, and weaker evidence of discrimination in women's favor in low-price restaurants. Of the 12 job offers from high-price restaurants, 10 were made to men. In contrast, of the 11 job offers from low-price restaurants, nine were made to women. In addition, information gathered from the restaurants in the study suggests that earnings are substantially higher in high-price restaurants, so that the apparent hiring discrimination that we find has implications for sex differences in earnings among waitpersons. The following sections describe the study fully, and provide a statistical analysis of the data we collected.

\section{The Study}

The principle underlying our study was to try to get as close as possible to the following experiment: send pairs of men and women, who are identical in every respect except their sex, to apply for jobs at restaurants in different price categories, and observe whether there are any statistically significant differences between the sexes in the receipt of job offers in each price category. We took numerous steps to get as close to this ideal experiment as possible.

The first step was to make the male and female applicants identical on paper. To do this, we created a set of three resumes that were quite similar in terms of personal history and past work experience. Although the resumes were designed to be similar, to avoid sex 
differences in outcomes that might be attributable to differences in the impressions potential employers gained from the resumes, the resumes were rotated among the job applicants over the course of the study. Specifically, over the three-week period during which the resumes were dropped off at restaurants, each of the two men and two women used each resume for one week. Of course, the name and telephone number of the applicant at the top of the resume was changed to correspond to the person using the resume. ${ }^{4}$

Each resume indicated that the applicant had some experience in both local restaurants and national chains. To boost the likelihood of job offers from restaurants in the high-price category, where we suspected offers might be harder to obtain, each resume was designed to convey the type of experience and knowledge that might make an applicant attractive to such restaurants. Thus, two of the resumes indicated some involvement in restaurant-related activities (such as wine tasting), while the third emphasized the high quality and range of the applicant's previous experience. In addition to restaurant and restaurant-related experience, each resume also indicated some general retail experience, a high-school education, some involvement in social action, and personal interests that were not strongly sex-typed (since men and women had to use the resumes). Finally, in order to minimize employers checking references, possibly through personal contacts with other restauranteurs in Philadelphia, each resume indicated that the candidate had come from another city, and acquired their work experience in that city. ${ }^{5}$ The three resumes are reproduced in the Appendix.

The second step was to minimize the effects of differences in personality or

${ }^{4}$ One of the individuals had a name that was sex-neutral. Since we wanted potential employers to know the sex of the job applicant, this person used a different, traditionally female name for the course of the study.

${ }^{5}$ We received no indication from any of the potential employers that they had checked on the job references on the resumes. 
appearance that might affect job offers, and that might be related to sex. Four elements of the research design address this concern. First, two men and two women were used to search for jobs, rather than just one of each sex. ${ }^{6}$ Second, we attempted to reduce the effects of personality differences by having the job applicants, as much as possible, maintain an even demeanor and similar appearance throughout all contacts with the restaurants. Of course, especially in the absence of a larger sample of job applicants, it is always possible to attribute any sex difference in outcomes to remaining differences in personality or appearance.

Two additional elements of the study potentially go much further in eliminating this problem. First, we look for sex differences in the receipt of job offers in different price categories of restaurants. If males or females turn out to be relatively favored in all three price categories, then an interpretation based on differences in personality or appearance might be difficult to refute. However, if males are favored in one price category (such as high-price restaurants), and females in another category, then such an interpretation is less tenable, unless different characteristics of personality or appearance are valued in restaurants in different price categories.

Second, while hiring decisions were based on interviews in which personality and appearance can play a role, we endeavored to get employers to make a decision regarding whether or not to interview an applicant based solely on the information on the resumes. In particular, when the job applicants stopped into restaurants, the strategy they followed was to give their resume to the first employee they encountered. This was frequently a host, or a

${ }^{6}$ In fact, one potential problem arose because one of the female students in the research seminar that provided the job applicants was Asian. Thus, when we test for sex differences in outcomes, we ask if the results differ whether we compare outcomes for both men and women, or just for both men and the non-Asian woman. 
waitperson or busperson setting up, since we tried to have applicants stop into restaurants during times when business was slow, such as the late morning. The applicant requested that this employee give the resume to the owner or manager, with instructions to call if there was any possibility of being interviewed for the job. Because interviews are based almost solely on the information from the resumes, a comparison of results for receipt of interviews and job offers can be used to gauge the role of differences in personality or appearance. If there are no differences in outcomes by sex for interviews, but there are for job offers, then it is possible that personality or appearance differences affect the outcomes. However, sex differences in outcomes at the interview stage are much more difficult to attribute to personality or appearance differences. ${ }^{7}$

Because we were interested in differential treatment of men and women in restaurants in different price categories, we used Zagat's Philadelphia Restaurant Guide to identify three price categories: high-price (average meal price over $\$ 30$ ); medium-price $(\$ 15-\$ 30)$; and low-price (less than $\$ 15$ ). ${ }^{8}$ We did not restrict attention to restaurants advertising for positions, since some initial "trial runs" of our job application procedure revealed that restaurants hired on a fairly continual basis, generally without advertising. We avoided strictly ethnic restaurants since we suspected they might prefer to hire members of the same ethnic group, although this, of course, might be regarded as discriminatory.

Over a three-week period in the spring of 1994, pairs of male and female job

${ }^{7}$ This principle is also exploited in a study by McIntyre, et al. (1980), who compare differential responses of companies to fictitious resumes made comparable by randomizing across the entries on the resume, and then randomly indicating sex or race. This study found significant evidence of more favorable responses to men than to women.

${ }^{8}$ According to Zagat's, these prices are based on dinner including an appetizer, main course, and one drink, and excluding the tip. 
applicants dropped off resumes at 65 restaurants (just over 20 per week). In each week, applications were made to restaurants in all three price categories. The pairings of males and females and the order in which the resumes were dropped off (male or female first) were alternated from restaurant to restaurant, to attempt to avoid any systematic biases in the estimated outcomes by sex. Of the 130 job applications, as of approximately one month after we completed dropping off the resumes, 54 resulted in job interviews, and 39 of those interviews resulted in job offers. ${ }^{9}$

\section{Results}

Descriptive Statistics

Table 1 reports the raw data from the study. Panel A summarizes results for job offers. The first six rows indicate the proportion of job applications resulting in job offers for each of the applicants, in each price category of restaurants. The two male applicants had very similar results; each received offers from the high- and medium-price restaurants in about one-half of the cases (five or six offers), and each received one offer from the lowprice restaurants. Male 1 had a slightly higher job offer rate at the medium-price restaurants, and male 2 had a slightly higher job offer rate at the high-price restaurants.

Overall, the job offer rates for the males were $.48, .48$, and .10 in the high-, medium-, and low-price restaurants, respectively. The results for the two females differ somewhat more. ${ }^{10}$ Female 1 had a higher job offer rate at the medium-price restaurants (.45 versus .10$)$, while female 2 had a higher rate at the low-price restaurants (.56 versus .25$)$. However, neither

${ }^{9}$ No job offers were made without interviews.

${ }^{10} \mathrm{Female} 2$ is the Asian female. 
female had much success at the high-price restaurants; each received just one job offer.

Overall, the job offer rates for the females were $.09, .29$, and .38 in the high-, medium-, and low-price restaurants, respectively. Thus, the raw data strongly suggest hiring discrimination against women in high-price restaurants, and in favor of women (although less strongly so) in low-price restaurants.

The next four rows summarize the data differently, focusing on the outcomes for male-female pairs of job applicants. Outcomes for pairs will reveal any evidence of asymmetric treatment of men and women. As Heckman and Siegelman emphasize, the best measure of discrimination in audit studies is the difference between the proportion of pairs in which the male gets an offer, but the female does not, and the proportion in which the reverse occurs. ${ }^{11}$ The figures reveals asymmetric treatment in favor of men in high-price restaurants, where the difference between these proportions is $.39(.43-.04)$. In low-price restaurants, in contrast, the figures suggest asymmetric treatment in favor of women; the proportion of pairs in which an offer is made to a female but not a male exceeds the proportion in which the reverse occurs by $.29(.29-.00)$.

Finally, the last two rows of Panel A report p-values from statistical tests of the null hypothesis of symmetric treatment of males and females. The likelihood ratio test is a large sample test, while the conditional sign test is an exact small sample test which conditions on the number of pairs with unequal outcomes (i.e., an offer to only one member of the pair). Details regarding these tests are provided in Heckman and Siegelman (1992). The easiest way to interpret the tests is in terms of the p-values, which indicate the probability that the

\footnotetext{
${ }^{11} \mathrm{Heckman}$ and Siegelman argue that this is a better measure than simply testing whether the proportion of pairs in which males receive offers but females do not is significantly different from zero, since this test ignores the possibility of an equal proportion of pairs in which females receive offers but males do not.
} 
observed outcome would have occurred if there were in fact symmetric treatment of males and females; probabilities below .05 indicate statistically significant evidence against the null hypothesis of symmetric treatment. In this case, the two tests provide similar results. There is statistically significant evidence of discrimination against women in high-price restaurants, and against men in low-price restaurants. ${ }^{12}$

Heckman and Siegelman also focus on whether it is appropriate to pool observations across pairs of job applicants, which essentially asks if a subset of the pairs of applicants drives the results, possibly because in that pair, the male and female were not well matched. For example, if any one of the applicants created a persistently positive or negative impression, the results for job offers could be contaminated, although this would most likely show up in asymmetric outcomes in all price categories of restaurants. Because we alternated the pairings of males and females, tests for pooling are complicated by the fact that observations from different pairs are not independent. However, the possibility with which we are most concerned is that the results are driven by pairs in which males were matched to female 2, since female 2 was Asian, and may have experienced discrimination for this reason. To explore this possibility, Appendix Table 1 repeats the analysis of Panel A of Table 1 using only pairs involving female 1 . For this subset of the data, the figures in Panel A of the appendix table indicate statistically significant evidence of discrimination against women in high-price restaurants. However, because female 2 was relatively more successful in obtaining offers in low-price restaurants, the evidence of discrimination in favor of women

\footnotetext{
${ }^{12}$ Unless otherwise noted, statements regarding statistical significance refer to the fivepercent significance level.
} 
in low-price restaurants is now weaker, and not statistically significant. ${ }^{13}$

In Panel B of Table 1, we report results for interviews. The results are qualitatively similar to those for job offers, although the evidence of discrimination in favor of women in low-price restaurants is weaker. The interview rates for men were $.61, .62$, and .19 in the high-, medium-, and low-price restaurants, respectively, compared with $.26, .43$, and .38 for women. The figures reveals asymmetric treatment in favor of men in high-price restaurants; the difference between the proportion of pairs in which only males receive interviews, and the proportion in which only females receive interviews, is $.35(.48-.13)$. In low-price restaurants the figures suggest asymmetric treatment in favor of women; the corresponding difference in proportions is $.19(.29-.10)$. Finally, the statistical tests of the null hypothesis of symmetric treatment lead to rejection of the null only for the high-price restaurants. The results are similar in Appendix Table 1, for the subset of pairs including female 1 only.

Finally, Panel $\mathrm{C}$ reports offers as a fraction of interviews. In some sense, these numbers are less useful. If there were discrimination in interviewing, but not in job offers conditional on receiving an interview, we would still get strong sex differences in job offers. ${ }^{14}$ Furthermore, we cannot analyze outcomes for pairs for this subsample, since, as Panel B shows, there are relatively few pairs in which both the male and the female receive interviews. Finally, the sample is relatively small. Nonetheless, it is of interest to know whether, conditional on an interview, outcomes appear to differ by sex. The numbers in Panel $\mathrm{C}$ suggest that in high-price restaurants there is discrimination against women in job

${ }^{13}$ In the multivariate analysis that follows, we also control for the pooling problem by including dummy variables for the male-female pair from which each observation is drawn.

${ }^{14} \mathrm{Also}$, as noted above, job offer decisions may be influenced more by personality and appearance than are job interview decisions. 
offers following an interview. In these restaurants, the offer rate for women was .33, compared with .79 for men. In contrast, women appear to be favored in low-price restaurants, with an offer rate of 1.0 , compared with .50 for men.

\section{Multivariate Analyses}

The following tables report results from probit analyses of the data, which allow us to test the statistical strength of the relationships in Table 1 once we control for some other potential influences on the job offer and interview decisions, and allow for the nonindependence of outcomes for job applications to the same restaurant.

Table 2 reports probit estimates for job offers. For each specification, the coefficient estimates have been transformed to give the marginal effect of the variable on the probability of a job offer, evaluated at the sample means. The standard errors of this nonlinear function

of the estimated coefficients are obtained using a first-order Taylor series approximation. All specifications include dummy variables for high- and low-price restaurants, and interactions between a dummy variable for female and dummy variables for high-, medium-, and lowprice restaurants. Thus, the coefficient of female $\times$ high-price measures the effect of being female on the probability of receiving a job offer from high-price restaurants, relative to male applicants in high-price restaurants. The coefficient of female $\times$ low-price measures the effect of being female on job offers from low-price restaurants, relative to male applicants in low-price restaurants. Finally, the coefficient of female $\times$ medium-price measures the effect of being female on job offers from medium-price restaurants, relative to male applicants in medium-price restaurants. Note that these female $\times$ price-category coefficients capture the same asymmetric treatment as do the univariate tests considered in 
Table 1, since they measure net sex differences in outcomes. ${ }^{15}$

For each specification, a random effects probit model is used that allows for a restaurant-specific as well as an application-specific error component. This estimator allows observations on outcomes for two applicants to the same restaurant to be dependent, rather than independent as is assumed in the conventional probit model. ${ }^{16}$

The first specification, reported in column (1), includes only the price category dummy variables, and the interactions of these with the female dummy variable. The female job applicants were significantly less likely to receive job offers at the high-price restaurants. The estimated probability of receiving a job offer is lower by .48 for women, an estimate that is statistically significant. On the other hand, female job applicants were significantly more likely to receive job offers in low-price restaurants. The estimated probability of receiving a job offer is higher by .39 for women, which is statistically significant at the 10 percent level.

The resumes were designed to provide impressions of job applicants that were roughly equivalent. In addition, as mentioned above, the resumes were rotated among job applicants, so that each resume was used approximately the same number of times by men and women. Nonetheless, to assess whether the distribution of the resumes affects the results, the specification in column (2) includes dummy variables for the resume that the job applicant used, while the specification in column (3) also includes interactions between these dummy variables and dummy variables for restaurant price categories. As was intended in the design of the resumes, the estimated effects of the resume dummy variables and their interactions on

\footnotetext{
${ }^{15}$ This argument is formalized in Appendix 1.B of Fix, et al. (1992).

${ }^{16}$ This approach is also used in Kenney and Wissoker (1994).
} 
the probability of a job offer are small and statistically insignificant. In addition, likelihood ratio tests indicate that the exclusion of these resume variables from the equation cannot be rejected. Twice the difference in log likelihoods is 1.0 , comparing column (2) to column (1), and 1.2, comparing column (3) to column (1), versus five-percent critical values of 5.99 and 12.59 respectively. Finally, the estimated sex differences in the probability of receiving a job offer from restaurants in different price categories are virtually unchanged when the resume controls are included.

The next set of specifications, in columns (4) and (5), examine the pooling problem raised by Heckman and Siegelman (1992), by asking whether the results are driven by particular pairings of applicants. To explore this question, in column (4) we include dummy variables for the possible pairings of males and females. ${ }^{17}$ In case the sensitivity of the results to these pairings depends on the price category, in column (5) we also include interactions between these pair dummy variables and price category dummy variables. The estimates in column (4) indicate that the effects of the pairings are near zero and statistically insignificant. However, in column (5) we obtain a t-statistic exceeding one for the dummy variable indicating a pairing with male 2 , in the low-price restaurants. However, likelihood ratio tests indicate that these variables can be excluded, and the estimated sex differences in the probability of receiving a job offer from restaurants in different price categories are virtually unchanged when the pairing controls are included. Nonetheless, in the remaining specifications we retain the one variable for which the t-statistic exceeded one.

The data in Table 1 indicate that female 2 had relatively more success in low-price

${ }^{17}$ Since there is already an intercept shift (for each price category) associated with sex, we need only to include a dummy variable distinguishing pairings of males with one of the females, and pairings of females with one of the males. 
restaurants, relatively less success in medium-price restaurants, and lower success overall. Thus, in the specification in column (6) we add a dummy variable for female 2 , and in column (7) we add interactions of this variable with dummy variables for low- and high-price restaurants. Not surprisingly given the numbers in Table 1 , the estimated effect of the dummy variable for female 2 in column (7), which measures the difference in outcomes between her and female 1 in medium-price restaurants, is negative and statistically significant at the 10-percent level. The estimated differences in the high- and low-price restaurants are positive, but not statistically significant. The estimated coefficient of female $\times$ high-price now measures the difference in the probability of a job offer between female 1 and the two male job applicants. This estimated difference is still significantly lower (by .41-.51). However, since female 2 had a higher success rate at low-price restaurants than did female 1 , the estimated sex difference in the probability of receiving a job offer at low-price restaurants is no longer as large, nor statistically significant.

Table 3 turns to the same set of specifications for the probability of receiving an interview. Given the detailed discussion of the previous table, the results from this table can be quickly summarized. For low-price restaurants, until we include the controls for female 2 , the estimated difference in the probability of an interview for female job applicants is positive, but never statistically significant. Once we include these controls, the estimated effect is near zero. For high-price restaurants, however, the results are very similar to those for job offers. In nearly all of the specifications, the probability of receiving an interview in a high-price restaurant is significantly lower for female job applicants, with the estimates in 
the range $.38-.55 .^{18}$

Finally, Table 4 turns to estimates of the job offer equation for the sample of job applicants that received interviews. There is an obvious sample selection problem here, but given that the same variables presumably affect interviews and hires, it seems fruitless to try to identify the sample selection mechanism. We also have to exclude observations on female applicants in low-price restaurants because, as Table 1 shows, female $\times$ low-price is a perfect predictor of job offers for this subsample. In addition, the data set includes many observations from which the observation on the other applicant in the pair is dropped, because that applicant did not receive an interview. Thus, we can no longer estimate the random effects specification, and instead report conventional probit estimates. Finally, many of the interactive variables included in the previous tables could not be included in the models for this subsample, because the interactions were perfectly collinear with the included variables, or were perfect predictors of the outcome. Consequently, Table 4 reports a more limited set of specifications. In brief, the estimated probability that females receive job offers in high-price restaurants is lower by $.35-.51$. The estimated differences are significant at the 10-percent level or better in three of the four specifications. Because none of the estimated effects of the control variables for resumes, pairs, or female 2 are anywhere near statistically significant, the specification in column (1) is preferred, in which the sex difference in outcomes at high-price restaurants is significant at the six-percent level.

\footnotetext{
${ }^{18}$ The only exception is column (6), which includes a dummy variable for female 2 , but excludes the interactions between this variable and dummy variables for price categories. A likelihood ratio test rejects the restricted specification in column (6) in favor of the specification in column (7).
} 


\section{Earnings Differences}

The audit results indicate hiring discrimination against women in high-price restaurants. However, as discussed in the Introduction, there is no existing hard evidence that earnings are higher in high-price restaurants than in low- or medium-price restaurants, although this has typically been assumed. If such earnings differences do not exist, then the pattern of hiring discrimination that we have uncovered may be relatively unimportant from the perspective of explaining the sex gap in earnings among waitpersons.

While this question was not the principle focus of this project, we did gather some informal survey evidence via telephone interviews with the restaurants in our sample some time following the audit study. We telephoned the restaurants during non-peak hours, and attempted to talk with a manager, telling them that we were engaged in a small-scale research project on earnings in entry-level jobs. We generally reached a manager, but were occasionally put in touch with a waitperson. We asked for that person's best estimate of the hourly earnings of waitpersons (wages plus tips). In general, there was a great deal of reluctance to discuss tip income, since the IRS works rather hard to monitor compliance with tax payments on tip income. ${ }^{19}$ In addition, even among those respondents willing to talk, some refused to be pinned down to any earnings estimates, and others did so only after being assured that we were only seeking their best estimate, and understood that earnings of waitpersons could be highly variable, and that tip earnings were often unknown to managers. Other restaurants were unwilling to talk for other reasons, and a few had closed.

Table 5 reports the information we were able to obtain, from 28 of the 65 restaurants in the audit sample. For each restaurant, we report the information as provided to us, and

\footnotetext{
${ }^{19}$ See, e.g., the Internal Revenue Service's Tip Income Study.
} 
then the minimum, maximum, and midpoint of the implied (or reported) hourly earnings. For each price category of restaurants, we report the average minimum, maximum, and midpoint of hourly earnings using the figures reported directly, the averages when we fill in the missing minimum and maximum (and sometimes midpoint) with the available data, and the averages when we drop the high and low values for each category. Regardless of how we calculate average hourly earnings, the data indicate large earnings premiums in high-price restaurants relative to both medium- and low-price restaurants, and smaller premiums in medium-price relative to low-price restaurants. For example, using the averages for the midpoints deleting the highest and lowest values, average hourly earnings in high-price restaurants (\$18.57) are 47 percent higher than earnings in medium-price restaurants (\$12.61), and 68 percent higher than earnings in low-price restaurants $(\$ 11.08)$. The same qualitative conclusion emerges from comparisons of any of the other averages. Thus, the hiring advantage that men seem to enjoy in high-price restaurants likely translates into substantial earnings advantages.

\section{Conclusion}

Our results for job offers, interviews, and job offers conditional on interviews provide statistically significant evidence of sex discrimination against women in high-price restaurants. In high-price restaurants, job applications from women had an estimated probability of receiving a job offer that was lower by about .5 , an estimated probability of receiving an interview that was lower by about .4 , and an estimated probability of receiving a job offer, conditional on receiving an interview, that was lower by about .45 .

As discussed in the Introduction, occupational segregation has alternatively been attributed to differences in human capital investment, preferences, and discrimination. The 
research design used in this study isolates the effect of discrimination. We control for the effects of self-selection based on preferences or anticipated human capital investments by sending male and female job applicants to all restaurants, and we control for past human capital investment (and any other past differences) by presenting equivalent resumes to potential employers. Thus, we are quite confident in interpreting our results as reflecting discrimination.

However, the research design does not allow us to address the question of the nature of the discrimination. One plausible candidate is taste discrimination on the part of employers, employees, or customers, although in the case of employer or employee discrimination, it is difficult to explain why men appear to be segregated in high-price restaurants. A second candidate is statistical discrimination. If employers have to invest in their workers, and believe that women are likely to quit sooner than men, they may be reluctant to hire women. Conceivably, such investment could be more important in highprice restaurants, where service, knowledge, and formality may be more important. We speculate, however, that such considerations are relatively unimportant in explaining our results. First of all, some job history is provided on the resumes, and by design the applications from women show the same persistence on the job, on average, as do the applications from men. Second, the relative ease with which job offers were obtained, and the near equality of job offer rates (for both sexes combined) in the high- and low-price restaurants, suggests that there is relatively high turnover in all price categories of restaurants.

Our audit results indicate hiring discrimination against women in high-price restaurants. In addition, our less formal survey evidence suggests that wage and tip earnings are substantially higher in high-price restaurants. Therefore, the pattern of hiring 
discrimination that we have uncovered may go a long way towards explaining the sex gap in earnings among waiters and waitresses. 


\section{References}

Beller, Andrea H. 1982. "Occupational Segregation by Sex: Determinants and Changes." Journal of Human Resources Vol. 17, No. 3: 371-92.

Berch, Bettina. 1982. The Endless Day: The Political Economy of Women and Work (New York, NY: Harcourt Brace Jovanovich, Inc.).

Bergmann, Barbara. 1974. "Occupational Segregation, Wages and Profits When Employers Discriminate by Race or Sex." Eastern Economic Journal Vol. 1 (April-July): 103-10.

. 1986. The Economic Emergence of Women (New York, NY: Basic Books, Inc.).

Cross, Harry, with Genevieve Kenney, Jane Mell, and Wendy Zimmerman. 1990. Employer Hiring Practices: Differential Treatment of Hispanic and Anglo Job Seekers, Urban Institute Report 90-4 (Washington, D.C.: The Urban Institute).

Daymont, Thomas N., and Paul J. Andrisani. 1984. "Job Preferences, College Major, and the Gender Gap in Earnings." Journal of Human Resources Vol. 19, No. 3: 409-28.

Fix, Michael, George C. Galster, and Raymond J. Struyk. 1992. "An Overview of Auditing for Discrimination." In Michael Fix and Raymond J. Struyk, editors, Clear and Convincing Evidence: Measurement of Discrimination in America (Washington, D.C.: The Urban Institute), pp. 1-68.

Heckman, James J., and Peter Siegelman. 1992. "The Urban Institute Audit Studies: Their Methods and Findings." In Michael Fix and Raymond J. Struyk, editors, Clear and Convincing Evidence: Measurement of Discrimination in America (Washington, D.C.: The Urban Institute), pp. 187-258.

Howe, Louise Kapp. 1977. Pink Collar Workers (New York, NY: G.P. Putnam's Sons).

Internal Revenue Service, Department of the Treasury. 1990. Tip Income Study Publication $1530(9-90)$.

Kenney, Genevieve M., and Douglas A. Wissoker. 1994. "An Analysis of the Correlates of Discrimination Facing Young Hispanic Job-Seekers." American Economic Review Vol. 84, No. 3 (June): 674-83.

McIntyre, Shelby, Dennis J. Moberg, and Barry Z. Posner. 1980. "Preferential Treatment in Preselection Decisions According to Sex and Race." Academy of Management Journal Vol. 23, No. 4: 738-49.

Polachek, Solomon W. 1981. "Occupational Self-Selection: A Human Capital Approach to Sex Differences in Occupational Structure." Review of Economics and Statistics Vol. 58, No. 1 (February): 60-9. 
Rytina, Nancy. 1981. "Occupational Segregation and Earnings Differences by Sex." Monthly Labor Review (January): 49-52.

Sieling, Mark S. 1984. "Staffing Patterns and the Gender Pay Gap." Monthly Labor Review (June): 29-33.

Turner, Margery Austin, Michael Fix, and Raymond J. Struyk. 1991. Opportunities Denied, Opportunities Diminished: Racial Discrimination in Hiring, Urban Institute Report 91-9 (Washington, D.C.: The Urban Institute). 
Appendix: Resumes ${ }^{1}$

Resume \#1

Employment Objective

A full or part-time position as a food server.

\section{Education}

Lebanon High School, Lebanon, PA 17104.

Activities: Active in Lebanon YMCA youth outreach program. Mt. Hope Wine Group--a group organized to sample and critique the world's wines.

\section{Experience}

Stallions Bar and Grill: Front waiting in moderate to upscale dining institution. Responsible for food prep, dining room setup, and late night cocktail waiting, May 1993-February 1994. 1290 Front End Blvd., Harrisburg, PA.

Cesare Place: Front and back waiting in fine dining institution with a continental menu. Occasional work for Cesare Catering. Experience includes buffet service. Head waiter for last three months of employment and weekly hosting shift, January 1991-May 1993. 509 Washington Rd., Harrisburg, PA.

Red Lobster: Busperson and waitperson, June 1990-May 1991. West Valley Shopping Plaza, Harrisburg, PA.

Boscov's Department Store: Worked summers and Christmas as extra sales staff and cashier. Worked primarily in toys and sporting goods, June 1989-December 1990.

\section{Personal}

Basic understanding of retail computing systems and IBMs. Personal hobbies include exercise, reading, and piano playing.

${ }^{1}$ In the study, each of the three different resumes was produced with a different font and presentation style. Also, each resume included a name, telephone number, and address. 
Resume \#2

\section{Employment Objective}

A full or part-time position as a food server/waitperson.

\section{Education}

Kennedy High School, Chicago, IL.

Activities: Volunteer for the Urban Adult Literacy Program for the homeless. Big Brother/Big Sister program of Chicago.

\section{Experience}

Cafe Carlos: Wait position in fine dining institution (front waiting only). Via catering also had experience in bartending, buffet setup, interior design and food preparation, August 1992-February 1994. 1245 Front St., Chicago, IL.

Connections Restaurant and Bar: Lunch waitperson (back and front waiting), host and food prep. Summer only 1991-1993. 19 Broadway, Chicago, IL.

Ground Round: Wait position and busperson, February 1990-August 1991. Cherry Creek Mall, Chicago, IL.

Ritz Camera: Retail sales of photography equipment and photo developing. Experience with darkroom equipment and 1-Hour photo developing machinery. Cherry Creek Mall, Chicago, IL.

\section{Personal}

Basic use of Macintosh and IBM personal computing systems. Personal interests include photography, DJ'ing, and current affairs. 
Resume \#3

\section{Employment Objective}

A full or part-time position as a waitperson.

\section{Education}

Cedar Crest High School, Denver, CO.

Activities: Volunteer as senior companion in Silver Springs nursing home. Active in Denver's restaurant review guild.

\section{Experience}

Fleur: Waitperson in fine dining. Began as a busperson but worked up the ranks to head waiter within 2 years. In addition to fine dining wait skills and extensive wine knowledge, also had experience with scheduling, data analysis and catering, July 1991-February 1994. Westpoint Mall, Denver CO.

Jody's Grill and Bar: Front and back waiting with food prep. Also did cocktail waiting on an outdoor deck, March 1991-July 1991. Englewood, CO.

Perkins Restaurant: Busperson for fast paced family restaurant, summers and weekends, June 1989-July 1990. 578 Bridgeport Rd., Englewood, CO.

Safeway Supermarkets: Checkout teller in supermarket. Extensive customer service skills and computerized checkout system, January 1989-June 1989. Walnut Hill Rd., Englewood, $\mathrm{CO}$.

\section{Personal}

Excellent in use of data systems, computers, and registers. I enjoy reading, exercising, and fishing. 


\section{A. Offers/Applications (N)}

$\begin{array}{llll} & \text { High-price } & \text { Medium-price } & \text { Low-price } \\ \text { Male 1 } & .42(12) & .56(9) & .10(10) \\ \text { Male 2 } & .55(11) & .42(12) & .09(11) \\ \text { Both males } & .48 & .48 & .10 \\ \text { Female 1 } & .09(11) & .45(11) & .25(12) \\ \text { Female 2 } & .08(12) & .10(10) & .56(9) \\ \text { Both females } & .09 & .29 & .38 \\ \text { No offers } & .48 & .43 & .62 \\ \text { Offers to both } & .04 & .19 & .10 \\ \text { Offer to male only } & .43 & .29 & .00 \\ \text { Offer to female only } & .04 & .10 & .29 \\ & & & .00 \\ \text { Test of symmetry, } & & & .02 \\ \quad \text { p-value } & & .15 & \\ \text { Likelihood ratio test } & .00 & .11 & \\ \text { Conditional sign test } & .01 & \end{array}$

\section{B. Interviews/Applications (N)}

$\begin{array}{ll}\text { Male 1 } & .58(12) \\ \text { Male 2 } & .64(11) \\ \text { Both males } & .61 \\ \text { Female 1 } & .27(11) \\ \text { Female 2 } & .25(12) \\ \text { Both females } & .26\end{array}$

No interviews $\quad .26$

Interview both $\quad .13$

Interview male only $\quad .48$

Interview female only $\quad .13$

Test of symmetry,

p-value

Likelihood ratio test

Conditional sign test
.03

.02

\begin{tabular}{l} 
Medium-price \\
\hline $.67(9)$ \\
$.58(12)$ \\
.62 \\
$.73(11)$ \\
$.10(10)$ \\
.43
\end{tabular}

.29

.33

.29

.10

.15

.11
Low-price

$.20(10)$

$.18(11)$

.19

$.25(12)$

$.56(9)$

.38

.52

.10

.10

.29

.15

.11

C. Offers/Interviews (N)

$\begin{array}{ll}\text { Male 1 } & .71(7) \\ \text { Male 2 } & .86(7) \\ \text { Both males } & .79 \\ \text { Female 1 } & .33(3) \\ \text { Female 2 } & .33(3) \\ \text { Both females } & .33\end{array}$

$\frac{\text { Low-price }}{.50(2)}$
$.50(2)$
.50
$1.00(3)$
$1.00(5)$
1.00

The likelihood ratio and conditional sign tests are, respectively, large sample and small sample tests of the null hypothesis of symmetric treatment of males and females. Symmetry means that the probability that a pair of applicants obtains an offer (or interview) for the male but not the female equals the probability of an offer (or interview) for the female but not the male. Details are provided in Heckman and Siegelman (1992). 


\begin{tabular}{|c|c|c|c|c|c|c|c|}
\hline & (1) & (2) & (3) & (4) & (5) & (6) & (7) \\
\hline Female $\times$ high-price & $\begin{array}{l}-.48 \\
(.14)\end{array}$ & $\begin{array}{l}-.50 \\
(.15)\end{array}$ & $\begin{array}{l}-.50 \\
(.16)\end{array}$ & $\begin{array}{l}-.53 \\
(.18)\end{array}$ & $\begin{array}{l}-.52 \\
(.25)\end{array}$ & $\begin{array}{l}-.41 \\
(.18)\end{array}$ & $\begin{array}{l}-.51 \\
(.26)\end{array}$ \\
\hline Female $\times$ low-price & $\begin{array}{l}.39 \\
(.22)\end{array}$ & $\begin{array}{l}.41 \\
(.21)\end{array}$ & $\begin{array}{l}.40 \\
(.22)\end{array}$ & $\begin{array}{l}.34 \\
(.29)\end{array}$ & $\begin{array}{l}.21 \\
(.39)\end{array}$ & $\begin{array}{l}.19 \\
(.29)\end{array}$ & $\begin{array}{l}.17 \\
(.28)\end{array}$ \\
\hline Female $\times$ medium-price & $\begin{array}{l}-.19 \\
(.13)\end{array}$ & $\begin{array}{l}-.19 \\
(.13)\end{array}$ & $\begin{array}{l}-.19 \\
(.14)\end{array}$ & $\begin{array}{l}-.25 \\
(.16)\end{array}$ & $\begin{array}{l}-.09 \\
(.17)\end{array}$ & $\begin{array}{l}-.13 \\
(.14)\end{array}$ & $\begin{array}{l}-.01 \\
(.15)\end{array}$ \\
\hline High-price & $\begin{array}{c}.00 \\
(.14)\end{array}$ & $\begin{array}{l}.01 \\
(.15)\end{array}$ & $\begin{array}{l}.04 \\
(.23)\end{array}$ & $\begin{array}{l}.00 \\
(.14)\end{array}$ & $\begin{array}{l}.08 \\
(.18)\end{array}$ & $\begin{array}{l}-.00 \\
(.14)\end{array}$ & $\begin{array}{l}-.01 \\
(.15)\end{array}$ \\
\hline Low-price & $\begin{array}{l}-.49 \\
(.21)\end{array}$ & $\begin{array}{l}-.49 \\
(.21)\end{array}$ & $\begin{array}{l}-.47 \\
(.30)\end{array}$ & $\begin{array}{l}-.48 \\
(.22)\end{array}$ & $\begin{array}{l}-.36 \\
(.28)\end{array}$ & $\begin{array}{l}-.36 \\
(.23)\end{array}$ & $\begin{array}{l}-.41 \\
(.24)\end{array}$ \\
\hline Resume 2 & $\ldots$ & $\begin{array}{l}-.02 \\
(.13)\end{array}$ & $\begin{array}{l}-.01 \\
(.23)\end{array}$ & $\ldots$ & $\ldots$ & $\ldots$ & .. \\
\hline Resume $2 \times$ high-price & $\ldots$ & $\ldots$ & $\begin{array}{l}-.05 \\
(.29)\end{array}$ & $\ldots$ & $\ldots$ & $\ldots$ & $\cdots$ \\
\hline Resume $2 \times$ low-price & $\ldots$ & $\ldots$ & $\begin{array}{c}.03 \\
(.31)\end{array}$ & ... & ... & $\ldots$ & $\ldots$ \\
\hline Resume 3 & $\ldots$ & $\begin{array}{l}.09 \\
(.11)\end{array}$ & $\begin{array}{l}.11 \\
(.16)\end{array}$ & .. & .. & .. & $\ldots$ \\
\hline Resume $3 \times$ high-price & $\ldots$ & $\cdots$ & $\begin{array}{l}-.03 \\
(.28)\end{array}$ & .. & $\ldots$ & $\ldots$ & .. \\
\hline Resume $3 \times$ low-price & $\ldots$ & $\cdots$ & $\begin{array}{l}-.07 \\
(.29)\end{array}$ & $\ldots$ & .. & $\ldots$ & $\ldots$ \\
\hline Paired with female 2 & $\ldots$ & $\ldots$ & $\ldots$ & $\begin{array}{l}.00 \\
(.13)\end{array}$ & $\begin{array}{l}.16 \\
(.25)\end{array}$ & $\ldots$ & $\ldots$ \\
\hline $\begin{array}{l}\text { Paired with female } 2 \\
\times \text { high-price }\end{array}$ & $\ldots$ & $\ldots$ & .. & $\ldots$ & $\begin{array}{l}-.29 \\
(.32)\end{array}$ & $\ldots$ & .. \\
\hline $\begin{array}{l}\text { Paired with female } 2 \\
\times \text { low-price }\end{array}$ & $\ldots$ & $\ldots$ & $\ldots$ & $\ldots$ & $\begin{array}{l}-.10 \\
(.40)\end{array}$ & $\ldots$ & $\ldots$ \\
\hline Paired with male 2 & $\ldots$ & $\ldots$ & $\ldots$ & $\begin{array}{l}.10 \\
(.14)\end{array}$ & $\begin{array}{l}-.06 \\
(.24)\end{array}$ & $\ldots$ & $\ldots$ \\
\hline $\begin{array}{l}\text { Paired with male } 2 \\
\times \text { high-price }\end{array}$ & $\ldots$ & .. & .. & $\ldots$ & $\begin{array}{l}-.00 \\
(.45)\end{array}$ & $\ldots$ & $\ldots$ \\
\hline $\begin{array}{l}\text { Paired with male } 2 \\
\times \text { low-price }\end{array}$ & $\ldots$ & $\ldots$ & $\cdots$ & $\ldots$ & $\begin{array}{c}.44 \\
(.35)\end{array}$ & $\begin{array}{c}.46 \\
(.27)\end{array}$ & $\begin{array}{l}.29 \\
(.32)\end{array}$ \\
\hline
\end{tabular}


(1)

Female 2

Female $2 \times$ high-price

Female $2 \times$ low-price

$\rho$

Log-likelihood
(2)

(3)
(5)

(6)

$-66.9$

$-65.2$

Table reports effects on probability calculated as partial derivatives of probability of outcome with respect to variable. Asymptotic standard errors, computed using a first-order Taylor series approximation for the expression for this probability, and treating the sample means as fixed, are reported in parentheses. An intercept was included in all specifications. Female 2 is the Asian female. The random effects specification allows a common error component across job applicants to the same restaurant; $\rho$ is the correlation among residuals for applicants to the same restaurant. The interactions between paired with female 2 or paired with male 2 and price categories are defined subtracting off, e.g., the mean paired with female 2 from paired with female 2. Thus, the coefficients of high-price and low-price, multiplied by the probability of the outcome evaluated at the sample means, still measure the marginal effects of the price-category on the probability of the outcome. 


\begin{tabular}{|c|c|c|c|c|c|c|c|}
\hline & (1) & (2) & (3) & (4) & (5) & (6) & (7) \\
\hline Female $\times$ high-price & $\begin{array}{l}-.38 \\
(.14)\end{array}$ & $\begin{array}{l}-.39 \\
(.15)\end{array}$ & $\begin{array}{l}-.39 \\
(.17)\end{array}$ & $\begin{array}{l}-.50 \\
(.20)\end{array}$ & $\begin{array}{l}-.55 \\
(.19)\end{array}$ & $\begin{array}{l}-.28 \\
(.17)\end{array}$ & $\begin{array}{l}-.39 \\
(.18)\end{array}$ \\
\hline Female $\times$ low-price & $\begin{array}{c}.24 \\
(.17)\end{array}$ & $\begin{array}{c}.24 \\
(.18)\end{array}$ & $\begin{array}{c}.23 \\
(.19)\end{array}$ & $\begin{array}{c}.14 \\
(.21)\end{array}$ & $\begin{array}{c}.06 \\
(.28)\end{array}$ & $\begin{array}{c}.04 \\
(.25)\end{array}$ & $\begin{array}{c}.01 \\
(.24)\end{array}$ \\
\hline Female $\times$ medium-price & $\begin{array}{l}-.20 \\
(.18)\end{array}$ & $\begin{array}{l}-.20 \\
(.19)\end{array}$ & $\begin{array}{l}-.22 \\
(.21)\end{array}$ & $\begin{array}{l}-.31 \\
(.20)\end{array}$ & $\begin{array}{l}-.18 \\
(.24)\end{array}$ & $\begin{array}{l}-.08 \\
(.21)\end{array}$ & $\begin{array}{l}.13 \\
(.24)\end{array}$ \\
\hline High-price & $\begin{array}{l}-.01 \\
(.16)\end{array}$ & $\begin{array}{l}-.00 \\
(.17)\end{array}$ & $\begin{array}{l}.20 \\
(.25)\end{array}$ & $\begin{array}{l}.07 \\
(.19)\end{array}$ & $\begin{array}{l}.17 \\
(.25)\end{array}$ & $\begin{array}{l}.07 \\
(.19)\end{array}$ & $\begin{array}{l}.07 \\
(.19)\end{array}$ \\
\hline Low-price & $\begin{array}{l}-.49 \\
(.19)\end{array}$ & $\begin{array}{l}-.49 \\
(.19)\end{array}$ & $\begin{array}{l}-.47 \\
(.30)\end{array}$ & $\begin{array}{l}-.49 \\
(.19)\end{array}$ & $\begin{array}{l}-.40 \\
(.23)\end{array}$ & $\begin{array}{l}-.34 \\
(.20)\end{array}$ & $\begin{array}{l}-.41 \\
(.21)\end{array}$ \\
\hline Resume 2 & $\ldots$ & $\begin{array}{l}.04 \\
(.13)\end{array}$ & $\begin{array}{l}.21 \\
(.25)\end{array}$ & $\ldots$ & $\ldots$ & $\ldots$ & $\ldots$ \\
\hline Resume $2 \times$ high-price & $\ldots$ & $\ldots$ & $\begin{array}{l}-.44 \\
(.34)\end{array}$ & $\begin{array}{l}-.21 \\
(.20)\end{array}$ & $\begin{array}{l}-.22 \\
(.21)\end{array}$ & $\begin{array}{l}-.21 \\
(.20)\end{array}$ & $\begin{array}{l}-.19 \\
(.20)\end{array}$ \\
\hline Resume $2 \times$ low-price & $\ldots$ & $\ldots$ & $\begin{array}{l}-.04 \\
(.35)\end{array}$ & $\ldots$ & $\ldots$ & $\ldots$ & $\ldots$ \\
\hline Resume 3 & $\ldots$ & $\begin{array}{l}.15 \\
(.12)\end{array}$ & $\begin{array}{l}.23 \\
(.20)\end{array}$ & $\begin{array}{c}.09 \\
(.11)\end{array}$ & $\begin{array}{l}.08 \\
(.12)\end{array}$ & $\begin{array}{c}.09 \\
(.12)\end{array}$ & $\begin{array}{l}.10 \\
(.12)\end{array}$ \\
\hline Resume $3 \times$ high-price & $\ldots$ & $\ldots$ & $\begin{array}{l}-.21 \\
(.28)\end{array}$ & $\ldots$ & $\ldots$ & .. & $\ldots$ \\
\hline Resume $3 \times$ low-price & $\ldots$ & $\ldots$ & $\begin{array}{l}-.05 \\
(.30)\end{array}$ & $\ldots$ & $\ldots$ & .. & $\ldots$ \\
\hline Paired with female 2 & $\cdots$ & $\ldots$ & $\ldots$ & $\begin{array}{l}-.08 \\
(.14)\end{array}$ & $\begin{array}{c}.01 \\
(.27)\end{array}$ & $\cdots$ & $\cdots$ \\
\hline $\begin{array}{l}\text { Paired with female } 2 \\
\times \text { high-price }\end{array}$ & $\cdots$ & $\cdots$ & $\cdots$ & $\ldots$ & $\begin{array}{l}-.27 \\
(.35)\end{array}$ & $\ldots$ & $\cdots$ \\
\hline $\begin{array}{l}\text { Paired with female } 2 \\
\times \text { low-price }\end{array}$ & $\cdots$ & $\cdots$ & $\ldots$ & $\ldots$ & $\begin{array}{c}.07 \\
(.38)\end{array}$ & $\ldots$ & $\cdots$ \\
\hline Paired with male 2 & $\ldots$ & $\ldots$ & $\ldots$ & $\begin{array}{l}.13 \\
(.15)\end{array}$ & $\begin{array}{l}-.02 \\
(.25)\end{array}$ & $\ldots$ & ... \\
\hline $\begin{array}{l}\text { Paired with male } 2 \\
\times \text { high-price }\end{array}$ & $\cdots$ & ... & $\ldots$ & $\ldots$ & $\begin{array}{l}.05 \\
(.36)\end{array}$ & $\ldots$ & $\ldots$ \\
\hline $\begin{array}{l}\text { Paired with male } 2 \\
\times \text { low-price }\end{array}$ & $\cdots$ & $\cdots$ & $\cdots$ & $\cdots$ & $\begin{array}{l}.42 \\
(.36)\end{array}$ & $\begin{array}{l}.56 \\
(.28)\end{array}$ & $\begin{array}{c}.29 \\
(.37)\end{array}$ \\
\hline
\end{tabular}


Table 3 (continued)

(1)

(2)

(3)

(4)

(5)

(6)

(7)

Female 2

Female $2 \times$ high-price

Female $2 \times$ low-price

..

$\cdots$

$\begin{array}{lll}\cdots & -.25 & -.80 \\ & (.16) & (.36)\end{array}$

Female $2 \times$ low-price

$\rho$

$$
.14
$$

.13

(.32)

.14

.12

(.35)

(.35)

.14

.12

(.35)

Log-likelihood

$-80.8$

$-80.0$

$-78.4$

$-78.8$

$-77.3$

$-76.6$

$-73.2$

Table reports effects on probability calculated as partial derivatives of probability of outcome with respect to variable. Asymptotic standard errors of these derivatives are reported in parentheses. See footnote to Table 2 for additional details. 


\begin{tabular}{|c|c|c|c|c|}
\hline & (1) & (2) & (3) & (4) \\
\hline Female $\times$ high-price & $\begin{array}{l}-.44 \\
(.23)\end{array}$ & $\begin{array}{l}-.46 \\
(.23)\end{array}$ & $\begin{array}{l}-.35 \\
(.27)\end{array}$ & $\begin{array}{l}-.51 \\
(.29)\end{array}$ \\
\hline Female $\times$ medium-price & $\begin{array}{l}-.11 \\
(.21)\end{array}$ & $\begin{array}{l}-.11 \\
(.21)\end{array}$ & $\begin{array}{l}-.01 \\
(.26)\end{array}$ & $\begin{array}{l}-.12 \\
(.21)\end{array}$ \\
\hline High-price & $\begin{array}{c}.02 \\
(.19)\end{array}$ & $\begin{array}{c}.01 \\
(.19)\end{array}$ & $\begin{array}{c}.02 \\
(.19)\end{array}$ & $\begin{array}{c}.02 \\
(.19)\end{array}$ \\
\hline Low-price & $\begin{array}{l}-.26 \\
(.26)\end{array}$ & $\begin{array}{l}-.27 \\
(.27)\end{array}$ & $\begin{array}{l}-.27 \\
(.26)\end{array}$ & $\begin{array}{l}-.26 \\
(.26)\end{array}$ \\
\hline Resume 2 & $\ldots$ & $\begin{array}{l}-.12 \\
(.18)\end{array}$ & $\ldots$ & .. \\
\hline Resume 3 & $\ldots$ & $\begin{array}{l}-.17 \\
(.18)\end{array}$ & $\ldots$ & $\ldots$ \\
\hline Paired with female 2 & $\ldots$ & $\ldots$ & $\begin{array}{c}.10 \\
(.18)\end{array}$ & $\ldots$ \\
\hline Paired with male 2 & $\ldots$ & $\ldots$ & $\begin{array}{l}-.09 \\
(.24)\end{array}$ & $\ldots$ \\
\hline Female 2 & $\ldots$ & $\ldots$ & $\ldots$ & $\begin{array}{c}.15 \\
(.31)\end{array}$ \\
\hline Log-likelihood & -26.6 & -26.2 & -26.4 & -26.5 \\
\hline
\end{tabular}

Table reports effects on probability calculated as partial derivatives of probability of outcome with respect to variable. Asymptotic standard errors of these derivatives are reported in parentheses. See footnote to Table 2 for additional details. Because of the restriction to those receiving interviews, the panel was no longer balanced, so random effects estimates were not computed. Models were estimated for 46 applications out of the total of 54 applications for which interviews were received. Eight observations had to be dropped because female $\times$ low-price was a perfect predictor. Specifications including more detailed interactions with price categories were not estimated because many of these interactions were perfect predictors of the outcome, or were perfectly collinear with included variables. 
High-price restaurants:

1.

2.

3.

4.

5.

6.

7.

8.

9.

10.

Average

Average filling in all cells Average filling in all cells, deleting high and low values

Medium-price restaurants:

1.

2.

3.

4.

5.

6.

7.

8.

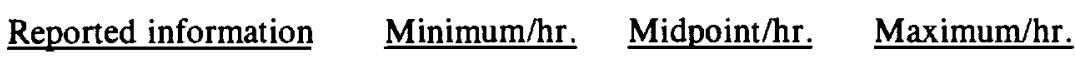

Minimum $\$ 30,000 / y r . \quad \$ 15.00$

Breakfast/lunch--

\$150-200/day for 9 hour shift

$\$ 16.67$

$\$ 19.44$

$\$ 22.22$

Dinner--\$50/hr.

$\$ 50.00$

$\$ 9.00$

Minimum $\$ 30,000 / y r . \quad \$ 15.00$

$\$ 150-175$ for $7-8$

$\$ 18.75$

$\$ 21.67$

$\$ 25.00$

hour shift

$\$ 18-23 / \mathrm{hr}$.

$\$ 18.00$

$\$ 20.50$

$\$ 23.00$

$\$ 15 / \mathrm{hr}$.

$\$ 15.00$

$\$ 20 / \mathrm{hr}$.

$\$ 20.00$

$\$ 14-17 / \mathrm{hr}$.

$\$ 14.00$

$\$ 15.50$

$\$ 17.00$

$\$ 25 / \mathrm{hr}$.

$\$ 25.00$

$\$ 16.24$

$\$ 21.79$

$\$ 20.56$

$\$ 18.57$

$\$ 21.81$

$\$ 19.67$

$\$ 17.49$

$\$ 21.47$

$\$ 19.69$

Lunch--\$40-60/4 hour shift

Dinner--\$50-70/

5-6 hour shift

$\$ 10.00$

$\$ 12.50$

$\$ 15.00$

$\$ 8.33$

$\$ 10.91$

$\$ 14.00$

$\$ 50-60 / 8-9$ hour shift

$\$ 5.56$

$\$ 6.47$

$\$ 7.50$

Lunch--\$40/4-hour

shift

Dinner--\$80/6-hour

shift

$\$ 10.00$

$\$ 13.33$

Day--\$200/wk., 5 shifts of 6-8 hours Night-- $\$ 400 /$ wk., 5 shifts of 6-8 hours

$\$ 5.00$

$\$ 5.71$

$\$ 6.67$

$\$ 10.00$

$\$ 11.43$

$\$ 13.33$

$\$ 12-15 / \mathrm{hr}$.

$\$ 12.00$

$\$ 13.50$

$\$ 15.00$

$\$ 16-17 / \mathrm{hr}$.

$\$ 16.00$

$\$ 16.50$

$\$ 17.00$

$\$ 18 / \mathrm{hr}$.

$\$ 18.00$

$\$ 15-22 / \mathrm{hr}$.

$\$ 15.00$

$\$ 18.50$

$\$ 22.00$ 


\section{Medium-price restaurants:}

Reported information Minimum/hr. Midpoint/hr. Maximum $/ \mathrm{hr}$.

9.

$\$ 12-15 / \mathrm{hr}$.

$\$ 12.00$

$\$ 13.50$

$\$ 15.00$

Average

Average filling in all cells

Average filling in all cells,

deleting high and low values

$\$ 12.53$

$\$ 13.94$

$\$ 11.27$

$\$ 12.53$

$\$ 13.90$

$\$ 11.22$

$\$ 12.61$

$\$ 13.82$

Low-price restaurants:

1.

2.

3.

4.

5.

6.

7.

8.

9.

Average
Average filling in all cells
Average filling in all cells,
deleting high and low values
Weekday--\$20-30/

9-hour shift

Weekend--\$60/9-hour

shift

$\$ 5.50-6.50 /$ hour

$\$ 9-13 / \mathrm{hr}$.

$\$ 15 / \mathrm{hr}$.

$\$ 15 / \mathrm{hr}$.

$\$ 8-15 / \mathrm{hr}$.

$\$ 10 / \mathrm{hr}$.

$\$ 14-15 / \mathrm{hr}$.

$\$ 13-15 / \mathrm{hr}$.

8.62

$\$ 9.84$

$\$ 10.15$

$\$ 5.50$

$\$ 9.00$

$\$ 8.00$

$\$ 14.00$

$\$ 13.00$
$\$ 2.78$

$\$ 3.33$

$\$ 6.67$

$\$ 6.00$

$\$ 6.50$

$\$ 11.00$

$\$ 13.00$

$\$ 15.00$

$\$ 15.00$

$\$ 11.50$

$\$ 15.00$

$\$ 10.00$

$\$ 14.50$

$\$ 15.00$

$\$ 14.00$

$\$ 15.00$

$\$ 10.65$

$\$ 10.65$

$\$ 11.31$

$\$ 11.45$

$\$ 12.02$

Midpoint estimates were constructed from midpoints of wage or earnings ranges and midpoints of ranges of hours per shift. "Average filling in all cells" is computed after filling in missing minimums and maximums with midpoints, and after filling in midpoints and maximums with minimums when only the latter are reported. 


\section{A. Offers/Applications}

$\underline{\text { High-price } \quad \text { Medium-price } \quad \text { Low-price }}$

$\begin{array}{llll}\text { No offers } & .45 & .36 & .75 \\ \text { Offers to both } & .09 & .27 & .08 \\ \text { Offer to male only } & .45 & .18 & .00 \\ \text { Offer to female only } & .00 & .18 & .17 \\ & & & \\ \text { Test of symmetry, } & & & .10 \\ \quad \text { p-value } & & & .25 \\ \text { Likelihood ratio test } & .01 & .38 & \end{array}$

\section{B. Interviews/Applications}

High-price $\quad$ Medium-price Low-price

$\begin{array}{llll}\text { No interviews } & .18 & .18 & .67 \\ \text { Interview both } & .18 & .55 & .08 \\ \text { Interview male only } & .55 & .09 & .08 \\ \text { Interview female only } & .09 & .18 & .17 \\ & & & \\ \text { Test of symmetry, } & & & .56 \\ \quad \text { p-value } & & & .56 \\ \text { Likelihood ratio test } & .05 & .38 & .38\end{array}$

Female 2 is the Asian female. See Table 1 for sample sizes and additional details. 